\title{
PENGARUH SUHU KADAR GARAM DAN WAKTU PENGOLAHAN BAKASANG IKAN TERI (Stolephorus Sp.) TERHADAP PARAMETER ANGKA PEROKSIDA
}

\author{
Verengki A Nainggolan ${ }^{1 *}$, Feti Fatimah ${ }^{1}$, Vanda Kamu ${ }^{1}$ \\ ${ }^{1}$ Jurusan Kimia Fakultas Matematika dan Ilmu Pengetahuan Alam Universitas Sam Ratulangi, \\ Jl. Kampus Unsrat, Kleak, Manado 95115 Sulawesi Utara
}

\begin{abstract}
ABSTRAK
Penelitian ini bertujuan mengetahui pengaruh suhu, kadar garam dan waktu terhadap pengolahan bakasang ikan teri dibuat dengan berbagai kondisi pengolahan. Analisis yang dilakukan dengan menggunkan parameter Angka Peroksida (AP) pada setiap sampel. Berdasarkan penelitian yang dilakukan nilai AP tertinggi yaitu dengan suhu $70{ }^{\circ} \mathrm{C}$, kadar garam $30 \%$ dan waktu fermentasi selama 10 Hari dengan nilai AP sebesar 6,181 meq ekivalen $\mathrm{O}_{2} / \mathrm{Kg}$, dan nilai AP terendah yaitu pada suhu $50{ }^{\circ} \mathrm{C}$, kadar garam $20 \%$ dan waktu fermentasi selama 3,29 Hari dengan nilai AP sebesar 0,966 meq ekivalen $\mathrm{O}_{2} / \mathrm{Kg}$. Tujuan dari penelitian ini adalah untuk menentukan pengaruh suhu, kadar garam dan waktu pengolahan (Variabel independen) terhadap parameter AP (Variabel dependen), maka diperlakukan beberapa metode statistika, pertama yaitu uji korelasi suhu, kadar garam dan waktu (variabel independen) terhadap nilai AP (variabel dependen) dengan hasil penelitian, berturut-turut $51,3 \% ; 33,3 \%$; dan $53,9 \%$. Selanjutnya adalah uji analisis varians (ANOVA), ANOVA dilakukan pada $95 \%$ confidence interval dengan nilai signifikansi $\alpha=0,05$, hasil signifikansi untuk variabel suhu, kadar garam dan waktu adalah 0,00.
\end{abstract}

Kata Kunci: Bakasang, ikan teri, angka peroksida

\section{ABSTRACT}

This research aims to determine the effect of temperature, salinity and time on the processing of anchovy Bakasang made with various processing conditions. The analysis was carried out using (Peroxide Value) PV parameters in each sample. Based on the research, the highest PV is at $70{ }^{\circ} \mathrm{C}$ temperature, $30 \%$ salinity and 10 days of fermentation time with $\mathrm{PV}$ of 6.181 meq ekivalen $\mathrm{O}_{2} / \mathrm{Kg}$, and the lowest $\mathrm{PV}$ is at $50^{\circ} \mathrm{C}$ temperature, $20 \%$ salinity and 3.29 day of fermentation time with $\mathrm{PV}$ of 0.966 meq ekivalen $\mathrm{O}_{2} / \mathrm{Kg}$. The aim of this research is to determine the effect of temperature, salinity and processing time (independent variables) on the PV parameter (dependent variable), so some statistical methods are needed, first, the correlation test of temperature, salinity and processing time (independent variable) on PV (dependent variable) with the research results, respectively $51.3 \%$; 33.3\%; and $53.9 \%$, next is the analysis of variance (ANOVA) test, ANOVA was carried out $95 \%$ confidence intervals with a significance value of $\alpha=0.05$, variable significance for temperature, salinity and time was 0.00 .

Keywords: Bakasang, anchovy, peroxide value

\section{PENDAHULUAN}

Indonesia memiliki sumber daya hayati laut yang sangat besar dengan kandungan berbagai macam jenis makhluk hidup di dalamnya. Salah satu jenis ikan yang banyak dikonsumsi warga di Sulawesi Utara adalah ikan teri. Ikan teri merupakan salah satu jenis ikan dari keluarga anchovy. Ukuran ikan teri berkisar antara 2-4 cm. Menurut Huss (1994) ikan teri sebagai bahan pangan yang mempunyai nilai gizi yang tinggi dengan kandungan mineral, vitamin,

\footnotetext{
* Korespondensi:

Telepon: +62 853-9856-6170

Email: verengkinainggolan79@gmail.com

DOI: https://doi.org/10.35799/cp.13.1.2020.28794
}

lemak tak jenuh dan protein, oleh sebab itu ikan teri layak masuk ke dalam golongan superfood, karena mempunyai banyak manfaat kesehatan dan bisa dikonsumsi oleh semua kalangan.

Ketersediaan ikan teri bisa sangat berlimpah pada musimnya. Pengolahan ikan teri oleh nelayan adalah dengan mengeringkan dibawah sinar matahari. Kondisi tersebut berbanding terbalik, karena musim panen ikan teri jatuh pada musim penghujan, sementara pengolahan pasca panen terhambat dikarenakan perlu sinar matahari dalam mengeringkan hasil yang berlimpah. Terdapat kesulitan 
mengolah ikan teri jika musim penghujan, bahkan beberapa kali terpaksa membuang ikan teri hasil tangkapannya. Berdasarkan informasi yang diberikan nelayan setempat ikan-ikan teri tersebut hanya dibiarkan membusuk di pinggir pantai (Tribun Manado, 2018). Oleh sebab itu perlu diversifikasi pengolahan ikan teri menjadi produk lain yang tidak tergantung pada cuaca/musim. Salah satunya adalah mengolahnya menjadi bakasang. Bakasang merupakan salah satu produk fermentasi spontan oleh mikroba fermentatif yang disebut bakteri asam laktat (Ijong dan Ohta 1995).

Di Sulawesi Utara khususnya di Kota Manado, pengolahan Bakasang dilakukan menggunakan bahan dasar jeroan ikan cakalang atau ikan-ikan kecil. Berdasarkan survey di lapangan diketahui, bahwa teknik pengolahan Bakasang di Manado juga masih dilakukan secara sangat sederhana, isi perut ikan biasanya dimasukkan bersama garam ke dalam botol/jerigen plastik, kemudian dijemur dibawah terik matahari beberapa hari hingga berubah menjadi cairan. Hal ini mendorong perlunya diadakan penelitian yang komprehensip tentang pemanfaatan ikan teri menjadi produk Bakasang guna meningkatkan diversifikasi produk perikanan.

Ketengikan oksidatif dapat disebabkan karena suhu yang tinggi, waktu fermentasi yang lama serta kadar garam yang tinggi, ketengikan oksidatif merupakan reaksi yang dihasilkan dari proses oksidasi lemak yang kompleks (Belitz \& Grosch, 1987). Salah satu uji yang digunakan untuk menentukan adanya ketengikan adalah Uji Angka Peroksida (AP).

Berdasarkan penelitian sebelumnya yang dilakukan oleh Fatimah dkk, (2017). Kondisi pengolahan berpengaruh terhadapa angka peroksida. Penelitian ini bertujuan untuk mengetahui pengaruh suhu, kadar garam dan waktu terhadap pengolahan bakasang ikan teri yang dibuat dengan berbagai kondisi pengolahan.

\section{BAHAN DAN METODE}

\section{Alat dan bahan}

Alat-alat yang digunakan adalah ferementor, pisau, sudip, timbangan digital, aluminium foil, oven, sendok plastic, cawan poeselin, cawan petri, desikator, erlenmeyer, hotplate, buret, pipet volumetrik, gelas ukur, gelas piala, tabung reaksi dan pipet tetes. Bahan utama yang digunakan untuk penelitian ini adalah ikan Teri, jeruk nipis, dan garam dapur. Bahan-bahan kimia yang dibutuhkan untuk analisis adalah aquades, asam asetat glasial, kloroform, kalium iodida, natrium tiosulfat, indikator amilum, campuran selenium, asam sulfat, natrium hidroksida, indikator mengsel dan n-Heksan.

\section{Pengolahan bakasang ikan teri}

Mengikuti prosedur Fatimah dkk., (2017) Pengolahan bakasang ikan Teri dilakukan sesuai dengan rancangan penelitian CCD (Rammo dkk, 2009) menggunakan tiga variabel yaitu suhu, kadar garam dan waktu, sedangkan respon yang digunakan adalah AP. Untuk pembuatan bakasang, ikan teri segar dicuci, selanjutnya ditiris dalam ayakan, dicampur dengan garam yang bervariasi dengan konsentrasi $(3,18 ; 10 ; 20 ; 30$; $36,82) \%$ dan dibiarkan berfermentasi dalam fermentor selama $(3,295 ; 5 ; 7,5 ; 10)$ hari dan pada suhu yang bervariasi $(16,36 ; 30 ; 50 ; 70 ; 83,64)^{\circ} \mathrm{C}$. Bakasang diaduk satu kali sehari di dalam fermentor sampai waktu yang ditentukan dan kemudian diambil untuk analisis.

\section{Angka peroksida}

Pengujian angka peroksida dilakukan dengan mengikuti prosedur AOCS (1998), ditimbang sebanyak $5 \mathrm{~g}$ sampel dimasukkan ke dalam labu Erlenmeyer ukuran $250 \mathrm{~mL}$, ditambahkan $30 \mathrm{~mL}$ larutan asam asetat dan kloroform dengan perbandingan 3:2, kemudian ditambahkan 0,5 mL larutan kalium iodida (KI), larutan dikocok dengan hati-hati agar tercampur, dan ditambahkan $30 \mathrm{~mL}$ aquades. Selanjutnya dilakukan titrasi larutan dengan $0,02 \mathrm{~N}$ natrium tiosulfat $\left(\mathrm{Na}_{2} \mathrm{~S}_{2} \mathrm{O}_{3}\right)$ hingga larutan berubah warna menjadi kuning. Setelah itu ditambahkan $0,5 \mathrm{~mL}$ larutan indikator kanji 1\% yang akan merubah warna larutan menjadi biru, titrasi kemudian dilanjutkan bersamaan dengan terus mengocok larutan hingga berubah warna menjadi biru muda yang menandakan pelepasan iodine dari lapisan kloroform, lanjutkan titrasi dengan hati-hati hingga warna biru pada larutan hilang. Nilai AP dapat dihitung dengan persamaan: Angka peroksida $=\frac{(\mathrm{S}-\mathrm{B}) \times \mathrm{N} \times 1000}{\left(\frac{\text { meq peroksida }}{\text { kg fat }}\right) \text { berat sampel }(\mathrm{g})}$

Keterangan: $\mathrm{S}=$ titrasi sampel, $\mathrm{B}=$ titrasi blanko, $\mathrm{N}=$ Normalitas $\mathrm{Na}_{2} \mathrm{~S}_{2} \mathrm{O}_{3}$

\section{Analisis data}

Analisis data digunakan untuk mencapai hasil penelitian yang komprehensif pertama yaitu uji korelasi antar variabel independen tarhadap Angka peroksida, selanjutnya adalah uji ANOVA yang digunakan untuk menguji signifikansi 
variabel yang berpengaruh pada proses pengolahan bakasang ikan Teri.

\section{HASIL DAN PEMBAHASAN}

\section{Hasil analisis angka peroksida}

Berdasarkan hasil pengujian AP bakasang ikan teri, nilai AP yang paling rendah dibandingkan dengan sampel lain yaitu $0,966 \mathrm{meq}$ peroksida/kg minyak, Sedangkan nilai AP paling tinggi ditunjukkan oleh sampel 8 sebesar 6,181 meq peroksida/kg minyak.

Tabel 1. Hasil analisis angka peroksida dengan berbagai kondisi pengolahan.

\begin{tabular}{llll}
\hline $\begin{array}{l}\text { Suhu } \\
\left({ }^{\circ} \mathrm{C}\right)\end{array}$ & $\begin{array}{l}\text { Kadar } \\
\text { Garam } \\
(\%)\end{array}$ & $\begin{array}{l}\text { Waktu } \\
\text { Fermentasi } \\
\text { (Hari) }\end{array}$ & $\begin{array}{l}\text { Angka } \\
\text { peroksida } \\
\text { (meq } \\
\text { ekivalen } \\
\left.\mathrm{O}_{2} / \mathrm{kg}\right)\end{array}$ \\
\hline 30 & 10 & 5 & 1,988 \\
70 & 10 & 5 & 3,197 \\
30 & 30 & 5 & 3,209 \\
70 & 30 & 5 & 3,693 \\
30 & 10 & 10 & 3,063 \\
70 & 10 & 10 & 5,065 \\
30 & 30 & 10 & 4,398 \\
70 & 30 & 10 & 6,181 \\
50 & 20 & 7,5 & 2,033 \\
50 & 20 & 7,5 & 2,098 \\
50 & 20 & 7,5 & 1,930 \\
50 & 20 & 7,5 & 1,899 \\
50 & 20 & 7,5 & 2,015 \\
50 & 20 & 7,5 & 2,001 \\
16,36 & 20 & 7,5 & 1,328 \\
83.64 & 20 & 7,5 & 5,791 \\
50 & 3,18 & 7,5 & 1,270 \\
50 & 36,82 & 7,5 & 3,798 \\
50 & 20 & 3,295 & 0,966 \\
50 & 20 & 11,705 & 5,145 \\
\hline
\end{tabular}

Nilai AP yang baik untuk minyak ikan menurut SNI 01-3741-2013 adalah maksimal sebesar $10 \mathrm{meq}$ peroksida/kg minyak. Angka peroksida yang melebihi standar dan sangat tinggi dapat menyebabkan tubuh mengalami keracunan jika dikonsumsi (Ketaren, 2012), mempercepat bau tengik dan flavor yang tidak diinginkan, serta bersifat racun bagi tubuh jika angka peroksidanya $>10 \mathrm{meq}$ peroksida/kg minyak (Nurhasnawati dkk, 2015). Berdasarkan pernyataan tersebut, dengan demikian dapat disimpulkan bahwa bakasang ikan teri dengan suhu, kadar garam dan waktu fermentasi dengan berbagai kondisi pengolahan sesuai dengan Tabel 1. masih dalam taraf aman karena tidak melebihi standar yang ditetapkan.

\section{Uji korelasi antar variabel (suhu, kadar garam dan waktu) terhadap nilai AP}

Analisis kolerasi mencoba mengukur kekuatan hubungan antara dua variabel melalui sebuah bilangan yang disebut koefisien kolerasi. Menurut Walpole (1996), koefisien korelasi merupakan ukuran hubungan linier antara dua peubah $\mathrm{x}$ dan $\mathrm{y}$, yang disimbolkan dengan " $\mathrm{r}$ ". Uji korelasi bertujuan untuk mengetahui tingkat hubungan pengaruh masing-masing variabel suhu, kadar garam dan waktu terhadap angka peroksida. Nilai korelasi antar variabel diperoleh dari hubungan linear x yang berupa suhu, kadar garam dan waktu terhadap nilai y yang berupa nilai AP. Koefisien korelasi mempunyai kisaran nilai antar "-1" (hubungan linier sempurna negatif), " 0 " (tidak ada hubungan dalam variabel) serta " 1 " (hubungan linier sempurna positif). Bila $\mathrm{r}$ mendekati +1 atau -1 , hubungan antar kedua variabel kuat dan terdapat korelasi yang tinggi antara keduanya . Hasil uji korelasi antara variabel suhu, kadar garam dan waktu terhadap nilai AP disajikan pada Tabel 2 .

Tabel 2. Korelasi tiga variabel proses terhadap nilai AP

\begin{tabular}{ll}
\hline Variabel $(\mathrm{x})$ & Nilai Koefisien $(\mathrm{r})$ \\
\hline Suhu & $0,513 *$ \\
Kadar Garam & 0,333 \\
Waktu & $0,539 *$ \\
\hline
\end{tabular}

Dengan tabulasi silang antara nilai AP terhadap setiap variabel, maka waktu fermentasi memiliki angka koefisien korelasi paling tinggi terhadap nilai AP. Berdasarkan Tabel 2 dapat diketahui bahwa korelasinya adalah 0,539 dan dibandingkan dengan variasi kadar garam dan suhu fermentasi yakni 0,333 dan 0,513 . Sudjana (2002) menyatakan bahwa korelasi memiliki 4 tingkatan yaitu tidak berkorelasi $(0-0,09)$, lemah $(0,1-0,25)$, cukup kuat $(0,26-0,49)$ dan sangat kuat $(>0,51)$. Tabel 2 menunjukkan bahwa waktu dan suhu fermentasi mempunyai korelasi sangat kuat dibandingkan dengan kadar garam yang memberikan korelasi cukup kuat, Semakin lama proses penyimpanan maka akan terjadi peningkatan angka peroksida pada minyak ikan, hal ini disebabkan terbentuknya reaksi kimia antara minyak dengan oksigen sehingga akan membentuk senyawa peroksida yang dapat membantu terjadinya proses oksidasi asam lemak 
tidak jenuh (Montesqrit, 2013). Hasan dkk, (2014), menyatakan oksidasi berjalan dengan cepat jika suhu penyimpanan cukup tinggi, terkena sinar matahari dan ada tidaknya pemberian antioksidan. Suhu dan waktu yang digunakan dalam pengolahan bakasang ikan teri merupakan salah satu faktor yang dapat mempercepat terjadinya oksidasi pada bakasang ikan teri, sehingga dapat diartikan bahwa waktu dan suhu pengolahan bakasang sangat berpengaruh pada penentuan nilai AP.

Uji signifikansi (suhu, kadar garam dan waktu) terhadap nilai AP

Signifikansi adalah besarnya probabilitas atau peluang untuk memperoleh kesalahan dalam mengambil keputusan (Walpole, 1996). Uji signifikansi melalui pengujian ANOVA ini bertujuan untuk mengetahui apakah ada pengaruh dari berbagai variabel suhu, kadar garam dan waktu yang diuji terhadap nilai AP. Selain itu, uji signifikansi dilakukan untuk mengetahui nilai koefisien determinasi $\left(\mathrm{R}^{2}\right)$ yang menunjukkan kekuatan tingkat kepercayaan terhadap data berdasarkan persamaan linear. Hasil uji signifikansi pada penelitian ini disajikan dalam Tabel 3.

Tabel 3. Hasil Pengujian ANOVA

\begin{tabular}{lccc}
\hline \multicolumn{1}{c}{ Sumber } & Df & $\mathrm{F}$ & Sig \\
\hline Model Koreksi & 14 & 645.740 & .000 \\
Intersep & 1 & 25391.764 & .000 \\
Suhu & 3 & 1117.179 & .000 \\
KadarGaram & 3 & 372.955 & .000 \\
Waktu & 3 & 1021.825 & .000 \\
Suhu*KadarGaram & 1 & 21.484 & .006 \\
Suhu*Waktu & 1 & 105.512 & .000 \\
KadarGaram*Waktu & 1 & 12.989 & .015 \\
Suhu*KadarGaram* & 1 & 6.173 & .056 \\
Waktu & 5 & & \\
Eror & 20 & & \\
Total & 19 & & \\
Total dikoreksi & & \\
$\mathrm{R}^{2}=.999\left(\mathrm{R}^{2}\right.$ disesuaikan $\left.=.998\right)$ &
\end{tabular}

Berdasarkan nilai signifikansi dari tiga variabel dalam fermentasi bakasang yang memberikan pengaruh signifikan adalah ketiga variabel suhu, kadar garam, dan waktu fermentasi. Nilai signifikansi ketiga variabel tersebut adalah 0,000 . Nilai tersebut kurang dari batas signifikansi yaitu 0,05 atau tingkat kepercayaan 95\%. Pengujian signifikansi ini membuktikan bahwa nilai AP dipengaruhi oleh variabel suhu, kadar garam, dan waktu fermentasi.
Koefisien determinasi $\left(\mathrm{R}^{2}\right)$ memiliki nilai berkisar antara $0-1$. Semakin kecil nilai $\mathrm{R}^{2}$ maka hubungan antar variabel semakin lemah, sebaliknya jika nilai $\mathrm{R}^{2}$ semakin mendekati 1 maka hubungan antar variabel dengan respon semakin kuat. Angka ini akan diubah dalam bentuk persen untuk mempermudah dalam menentukan besar maupun kecilnya pengaruh variabel. Batas penerimaan $R$ sebesar 0,60 (Sudjana, 2002). Dari Tabel 3, nilai $\mathrm{R}^{2}$ sebesar 0,999 yang artinya bahwa tingkat kepercayaan data pengaruh suhu, kadar garam dan waktu fermentasi bakasang ikan teri terhadap nilai AP sebesar 99,9\%. Pengaruh lain yang tidak dimasukkan ke dalam model atau variabel independen akan mempengaruhi jumlah persentase.

\section{KESIMPULAN}

Dalam fermentasi bakasang ikan teri ketiga variabel memberikan pengaruh terhadap nilai AP, variabel suhu memberikan pengaruh sebesar $51,3 \%$, variabel kadar garam memberikan pengaruh sebesar 33,3\%, dan variabel waktu fermentasi memberikan pengaruh sebesar 53,9\%, dan untuk nilai signifikansi untuk variabel suhu, kadar garam dan waktu adalah 0,000 , maka baik suhu, kadar garam dan waktu fermentasi mempunyai pengaruh signifikan yang besar terhadap nilai AP, dengan signifikansi tiga variabel $<0,05$, pengujian signifikansi ini membuktuktikan bahwa nilai AP sangat dipengaruhi oleh ketiga variabel ini.

\section{DAFTAR PUSTAKA}

AOCS American Oil Chemists Society. 1998. Official methods and recommended practices of the AOCS. Ed ke-4. Champaign Illinois: AOCS Press

Belitz, H.D., \& Grosch. 1987. Food chemistry. Berlin Heidelberg: Springer.

Fatimah, F., Pelealu, J.J., Gugule, S., Yempormase, H.V., \& Tallei, T.E. 2017. Quality evaluation of bakasang processed with variation of salt concentration, temperature and fermentation time. Pakistan Journal of Biological Sciences. 20(11), 543-551.

Hasan, B., Iriani. D., \& Densi. A. 2014. Pengaruh penambahan enzim visceral terhadap pematangan peda ikan kembung 
(Rastrelliger sp). Jurnal Teknologi Hasil Perikanan. 1(1), 1-9.

Huss H.H. 1994. Assurance of sea food quality. FAO Fisheries Technical Paper. 338 Rome. M-47 ISBN 92-5-103446-X, 169 pp.

Ijong, F.G., \& Ohta, Y. 1995. Amino acid composition of bakasang, a traditional fermented fish sauce from Indonesia. Journal of Microbiological Methods. 25(1), 236-237.

Montesqrit., \& Ovianti. R. 2013. Pengaruh suhu dan lama penyimpanan terhadap stabilitas minyak ikan dan mikrokapsul minyak ikan. Jurnal Peternakan. 15(1), 63-64.
Nurhasnawati, H., Supriningrum, R., \& Caesar, N. 2015. Penetapan kadar asam lemak bebas dan bilangan peroksida pada minyak goreng yang digunakan pedagang gorengan di jalan $\mathrm{A}$ W Sjahranic Samarinda. Jurnal Ilmiah Manuntung. 1(1), 25-30.

Rammo, N.N., Al-Amery, H.R., Abdul-Jabbar, T., \& Jaffer, H.I., 2009. Adhesion hardness and structure of thermal sprayed $\mathrm{al} /$ sic composite coat on graphite. Surface and Coatings Technology. 203(19), 28912895.

Sudjana. 2002. Desain dan analisis eksperimen, Edisi Keempat. Bandung: PT Tarsito.

Walpole, R.E. 1996. Pengantar statistika, edisi ke-3. Jakarta: Penerbit PT. Gramedia Pustaka Utama. 